\title{
Dinamika Psikologis Remaja Korban Perceraian: Sebuah Studi Kasus Kenakalan Remaja
}

\author{
Ardian Praptomojati ${ }^{1}$ \\ ${ }^{1}$ Fakultas Psikologi Universitas Gadjah Mada \\ ardian.praptomojati@gmail.com
}

\begin{abstract}
Parental divorce can be a very stressful experience for adolescents. Adolescents will lose their parent figure and feel different atmosphere in the family. This study aimed to identify the psychological dynamics of adolescents that have experienced parental divorce developing into juvenile delinquency. This was a case study research. The subject of this study was a 13-year-old boy with divorced parent and lived in an orphanage. Data were collected through observations, interviews, and psychological tests. The result revealed that juvenile delinquency happens because of the need of gaining attention from others. The wrong mindset "I will get attention if I commit juvenile delinquency and disturb others" became the basis of the subject's socially inappropriate behaviors. It was the way to compensate his inferior feelings.
\end{abstract}

Keywords : Adolescent, Parental Divorce, Juvenile Delinquency

\begin{abstract}
Abstrak. Perceraian orangtua dapat menjadi pengalaman yang sangat menekan bagi remaja. Remaja akan merasa kehilangan figur orangtua dan merasakan atmosfer keluarga yang berbeda. Penelitian ini bertujuan melihat dinamika psikologis remaja korban perceraian orangtua yang selanjutnya berkembang menjadi kenakalan remaja. Metode penelitian yang digunakan adalah studi kasus. Subjek penelitian merupakan seorang anak laki-laki berusia 13 tahun dengan orangtua yang telah bercerai dan tinggal di Panti Asuhan. Data dikumpulkan melalui observasi, wawancara, dan tes psikologi. Hasil penelitian menunjukkan bahwa kenakalan remaja terjadi karena didasari oleh kebutuhan subjek untuk mendapatkan perhatian dari lingkungannya. Adanya pola pikir yang salah, yaitu "Aku akan mendapatkan perhatian jika aku bandel dan mengganggu orang lain" menjadi dasar kenapa subjek berperilaku negatif. Perilakunya ini juga sebagai cara subjek untuk mengkompensasikan perasaan inferiornya.
\end{abstract}

Kata Kunci: Remaja, Perceraian Orangtua, Kenakalan Remaja

Keluarga merupakan lingkungan
yang sangat erat kaitannya dengan
pembentukan diri anak (Kagan, 1999; Mackay, 2005; Santrock, 2011; Wenar \& Kerig, 2006). Secara ideal, perkembangan anak dan remaja akan optimal apabila mereka bersama keluarga yang harmonis sehingga berbagai kebutuhan yang diperlukan dapat terpenuhi (Wenar \& Kerig, 2006). Dalam keluarga, peran orangtua menjadi faktor yang penting dalam perkembangan konsep diri (Emam \& Abu-Serei, 2014), efikasi diri (Mishra \& Shanwal, 2014), serta harga diri anak (Blattner, Liang, Lund, \& Spencer, 2013; Weber, 2001; Yabiku, Axinn, \& Thornton, 1999).

Indonesia menjadi salah satu negara dengan tingkat perceraian yang cukup tinggi. Data Badan Pusat Statistik (BPS) 
menunjukkan bahwa dari tahun ke tahun jumlah kasus perceraian di Indonesia mengalami peningkatan. Pada tahun 2013, tercatat ada 324.247 kasus talak dan perceraian, kemudian tahun 2013 jumlahnya meningkat menjadi 344.237 kasus, dan terakhir pada tahun 2015 tercatat ada 347.256 kasus talak dan perceraian (BPS, 2017).

Berbagai studi menunjukkan bahwa perceraian memberikan dampak yang besar bagi anak-anak mulai dari dampak ringan sampai berat, dari yang tampaknya kecil hingga sangat signifikan, dan dari yang jangka pendek hingga jangka panjang (Fagan \& Churchill, 2012). Berbagai studi menunjukkan bahwa anak korban perceraian dapat mengalami permasalahan perilaku (Aseltine, 1992; Babalis, Tsoli, Nikolopoulos, \& Maniatis, 2014; Morrison \& Coiro, 1999), permasalahan penyesuaian diri (Landsford, 2009), rendahnya kesejahteraan subjektif (Dewi \& Utami, 2008), permasalahan emosi (Aseltine, 1992), rendahnya kualitas hidup (Eymann, Busaniche, Llera, Cunto, \& Wahren, 2009), rendahnya harga diri (Esmaeili \& Yaacob, 2012), risiko tinggi terhadap depresi (Uphold-Carrier \& Utz, 2012), kecemasan (Pálmarsdóttir, 2015), kesepian dan ketidakpuasan hidup (Çivitci, Çivitci, \& Fiyakali, 2009), prestasi yang rendah di sekolah (Aseltine, 1992; Babalis et al., 2014), ketergantungan alkohol (Thompson Jr., Lizardi, Keyes, \& Hasin, 2008), risiko yang tinggi terhadap keterlibatan obat-obat terlarang (Needle, Su, \& Doherty, 1990), serta risiko munculnya perilaku antisosial dan kriminal (Wells \& Rankin, 1991).
Adofo dan Etsey (2016) dalam studinya menguraikan bahwa dampak perceraian orangtua bagi remaja dapat termanifestasikan dalam internalizing behavior ataupun externalizing behavior. Internalizing behavior meliputi ketakutan, rasa malu, depresi, rendahnya harga diri, kesedihan, kecemasan, kebingungan, rasa tidak aman, rasa sakit, dan rendahnya kepercayaan diri. Externalizing behavior meliputi perilaku agresi, kesulitan dalam menjalin hubungan dengan orang lain, ketidakmampuan untuk menyesuaikan diri dengan figur otoritas, perilaku bermasalah di sekolah, kenakalan remaja, perilaku mabuk-mabukan, perilaku seksual berisiko, mencuri, merokok, dan keterlibatan dengan obat-obat terlarang. Lebih jauh, riset menunjukkan bahwa remaja laki-laki memiliki kecenderungan yang lebih besar untuk mengalami permasalahan internalizing behavior dan externalizing behaviours daripada remaja perempuan.

Masa remaja menjadi periode yang sangat penting dan kritis dalam kehidupan manusia (Santrock, 2011). Hurlock (2002) menyebutkan bahwa masa remaja sering diibaratkan sebagai masa storm dan stress, masa transisi baik secara fisik maupun psikologis dari masa anak-anak menuju ke masa dewasa. Banyak studi menunjukkan bahwa remaja korban perceraian yang dibesarkan oleh orangtua tunggal memiliki risiko yang tinggi terhadap gangguan perilaku dan kenakalan remaja (Aseltine, 1992; Fagan \& Churchill, 2012; Fry, 2010; Singh \& Kiran, 2012; Thornberry, Smith, Rivera, Huizinga, \& Stouthamer-Loeber, 1999; Wenar \& Kerig, 2006). Ketidakhadiran salah satu figur orangtua dalam kehidupan 
remaja berpengaruh besar terhadap perkembangan dan kondisi psikologis remaja. Remaja akan mengalami krisis kasih sayang dan perhatian dari kedua orangtuanya sehingga ia pun merasa tidak aman secara emosional (emotionally insecure) (Fagan \& Churchill, 2012). Ia akan mengalami kebingungan, marah, dan putus asa sehingga mengarahkan kepada reaksireaksi perilaku di luar norma sebagai bentuk pelariannya. Thornberry dan koleganya (1999) menambahkan bahwa adanya perubahan-perubahan kondisi yang terjadi pada keluarga yang bercerai, menuntut remaja untuk dapat melakukan penyesuaian diri ke depannya. Ketika dia tidak mampu mengontrol kemarahan, tekanan, dan emosi negatif lainnya, maka mengarahkan pada perilaku kenakalan remaja dan perilaku maladaptif lainnya.

Berdasarkan Diagnostic and Statistical Manual of Mental Disorders (DSM-IV-TR), kenakalan remaja masuk dalam kategori conduct disorder, yang didefinisikan sebagai pola perilaku pelanggaran hak orang lain atau pelanggaran terhadap norma-norma sosial yang berulang dan menetap. Hal ini dapat termanifestasi dalam perilaku agresi terhadap orang atau hewan, perusakan terhadap properti orang lain, senang melakukan kecurangan, kebohongan, atau pencurian, dan pelanggaran norma-norma yang serius. Wenar dan Kerig (2006) menguraikan bahwa kenakalan remaja dapat dikategorikan dalam beberapa dimensi. Pertama, destructive (seperti kekejaman terhadap orang lain, penyerangan) dan nondestructive (menipu, melanggar aturan). Dimensi kedua fokus kepada apakah gangguan perilaku tersebut overt (memukul, berkelahi, penganiayaan) atau covert (berbohong, mencuri). Intensitasnya pun mulai dari mild (ringan), moderate (sedang), hingga severe (parah). Onset dapat terjadi pada masa anak-anak (awal usia 10 tahun) maupun masa remaja.

Melihat besarnya dampak negatif perceraian terhadap tingginya risiko kenakalan remaja, maka penting untuk mengetahui bagaimana dinamika psikologis remaja korban perceraian hingga akhirnya mengalami kenakalan remaja. Menjadi penting pula untuk menganalisis developmental pathway anak dengan melihat riwayat perkembangan anak selama hidupnya hingga terdeteksi munculnya permasalahan atau psikopatologi (Wenar \& Kerig, 2006). Hal ini untuk mengidentifikasi pada titik kapan anak atau remaja menunjukkan perilaku psikopatologis dan apa penyebab yang mendasari psikopatologi tersebut muncul dan berkembang dari track perkembangan yang awalnya normal menjadi abnormal. Pada penelitian ini, teori yang digunakan untuk membahas dinamika psikologis subjek adalah Teori Kognitif Keperilakuan. Teori Kognitif Keperilakuan menekankan bahwa perilaku abnormal dapat terjadi karena adanya kesalahan berpikir (distorsi kognitif) pada individu (Beck, 2011).

Berdasarkan uraian di atas, penelitian ini bertujuan untuk mengeksplorasi dinamika psikologis remaja korban perceraian yang selanjutnya berkembang menjadi kenakalan remaja. Pertanyaan penelitian yang diajukan adalah: 1) Bagaimana dinamika psikologis remaja korban perceraian hingga terjadi permasalahan kenakalan remaja? 2) Faktor 
protektif apa saja yang berperan di dalamnya? 3) Faktor risiko apa saja yang berperan di dalamnya?

\section{Metode}

Studi ini menggunakan pendekatan kualitatif dengan metode studi kasus untuk mendapatkan gambaran lebih jelas mengenai aspek-aspek yang diteliti. Subjek penelitian dalam penelitian ini adalah seorang remaja awal dengan kondisi kedua orangtuanya yang telah bercerai dan tinggal di Panti Asuhan. Subjek memiliki gangguan perilaku dan dilaporkan banyak pihak telah mengganggu lingkungan sekitarnya. Data penelitian diperoleh melalui observasi, wawancara, dan tes psikologi. Observasi dilakukan menggunakan metode pencatatan anecdotal record, yang bertujuan untuk mengetahui aktivitas dan interaksi subjek dengan anggota keluarga di rumah, di sekolah, dan juga di Panti Asuhan. Wawancara dilakukan terhadap orang tua, saudara (kakak dan adik), teman, guru, pramusosial, pekerja sosial, dan psikolog di Panti Asuhan. Tes psikologi yang diberikan meliputi asesmen kecerdasan yakni Standar Progressive Matrices (SPM) dan asesmen kepribadian, yakni Tes Proyektif (BAUM, DAP, HTP, dan Wartegg). Ketiga metode digunakan untuk meningkatkan kredibilitas penelitian kualitatif atau yang biasa disebut dengan triangulasi (Poerwandari, 2011). Berbagai data yang telah terkumpul kemudian dianalisis melalui beberapa tahapan. Pada mulanya, data-data diorganisasikan dan didapatkan tema-tema spesifik. Setelah data dipahami, peneliti melakukan analisis awal dengan cara memadatkan dan mengaitkan data. Peneliti mencoba menemukan pola dan hubungan dari tema-tema. Terakhir, temuan penelitian ditinjau menggunakan teori-teori psikologi sehingga didapatkan dinamika psikologis subjek penelitian.

\section{Hasil}

\section{Hasil Observasi dan Wawancara}

Subjek penelitian (selanjutnya disebut dengan Bagus) adalah remaja laki-laki berusia 13 tahun dan duduk di bangku kelas 6 Sekolah Dasar (SD). Bagus adalah anak kedua dari tiga bersaudara. Ia memiliki seorang kakak perempuan beda ayah dan seorang adik kandung laki-laki. Ibu Bagus hidup merantau dan cenderung berpindah-pindah. Ibu Bagus sudah bercerai dua kali. Bagus adalah anak dari pernikahan ibunya yang kedua. Perceraian pertama dikarenakan suami meninggalkannya. Pada pernikahan keduanya, Ibu Bagus merasa terpaksa karena dijodohkan oleh orangtuanya. Ibu dan ayah Bagus berpisah karena beberapa kali ibu memergoki ayah Bagus berusaha merenggut kegadisan anak pertamanya. Suami juga tidak pernah memberi nafkah dan bertanggung jawab pada keluarga. Ibu Bagus tinggal di sebuah rumah kontrakan kecil dengan luas tidak lebih dari $3 \times 5$ meter bersama kakak perempuan Bagus, sedangkan Bagus dan adiknya tinggal bersama di Panti Asuhan. Setiap dua minggu sekali di akhir pekan, Bagus dan adiknya pulang ke rumah.

Sejak kecil Bagus tinggal bersama ibu kandungnya. Pada usia 9 tahun, Bagus dititipkan di Pondok Pesantren. Karena tidak betah, maka ia kemudian 
dipindahkan ke Panti Asuhan. Beberapa alasan yang mendasari orangtua menitipkan Bagus ke Panti Asuhan antara lain: (1) keluarga memiliki kondisi ekonomi yang rendah sehingga kurang mampu memenuhi kebutuhan anak baik secara fisik dan pendidikan formal; (2) keluarga tidak punya tempat tinggal menetap; dan (3) hubungan keluarga inti dan keluarga besar yang kurang harmonis.

Sehari-hari, Ibu Bagus bekerja untuk membiayai hidup ketiga anaknya. Ibu Bagus mengaku merasa benci dengan ayah Bagus. Ibu cenderung tidak mengijinkan Bagus dan adiknya untuk tinggal bersama ayahnya karena dipandang memberi pengaruh yang buruk. Menurut hasil wawancara, sejak kecil Bagus dikenal sebagai anak yang aktif, susah diatur, mudah tersulut emosinya, dan bandel. Ibu Bagus kerap membandingkan Bagus dengan adiknya yang tergolong lebih penurut dan tidak bandel.

Hasil observasi dan wawancara menunjukkan bahwa Ibu Bagus adalah orangtua yang tergolong keras dan kaku. Jika berbicara dan memberitahu anak kerap kali menggunakan nada yang keras, bahkan tak jarang membentak dan memarahi. Ibu juga kerap menggunakan cara fisik jika anak dirasa bandel. Di rumah, Bagus kerap bertengkar dan berkonflik dengan ibunya. Ibu kerap melabeli Bagus secara negatif jika tidak mau menurut kepadanya. Bagus sendiri cenderung lebih banyak acuh jika disuruh ibunya. Tampak adanya hubungan yang kurang hangat antara Bagus dengan ibunya. Bagus juga kerap pergi tanpa pamit dari rumah terutama pada saat berkonflik dan marah dengan sang ibu.
Bagus memiliki kakak tiri perempuan yang sangat peduli dan perhatian kepadanya. Pada awal ketika ibu Bagus menikah dan mengandung Bagus, sang kakak sangat tidak senang dan membencinya. Kakak kerap berperilaku kasar dan kurang bersahabat dengan Bagus dan adiknya. Namun kini kakak merasa sangat sayang pada Bagus dan adiknya. Ia justu menjadi sosok yang peduli dengan pendidikan serta kehidupan Bagus dan adiknya.

Hasil wawancara kepada teman, pramusosial, dan pekerja sosial di Panti Asuhan mengungkapkan bahwa selama ini Bagus dipandang sebagai anak yang memiliki tingkat agresivitas tinggi. Bagus kerap mengganggu teman-temanya, berkata kasar, memukul, dan memprovokasi temannya untuk bertindak kasar. Ia juga kurang disiplin dan semaunya sendiri. Di sekolah, guru mengungkapkan bahwa hampir setiap harinya Bagus selalu berulah, entah itu mengusili temannya, berkata kasar, berteriak-teriak di kelas, ataupun ramai di kelas.

Hasil observasi menunjukan bahwa jika berinteraksi dengan anak yang lebih muda darinya, Bagus cenderung senang menjahilinya dan membuat ulah. Bagus akan berhenti menjahili sampai anak tersebut marah atau menangis atau setelah diingatkan oleh orang yang lebih dewasa. Jika diingatkan atau dinasihati oleh anak yang berada di bawah usianya atau seusianya, Bagus justru akan marah dan tidak terima. Bagus juga kerap memprovokasi temannya untuk bertindak kasar seperti memukul. Di sekolah, Bagus 
kerap ditegur oleh gurunya karena sering ramai sendiri dan mengganggu teman di kelasnya. Beberapa perilaku Bagus yang mencolok baik ketika di Panti Asuhan maupun di sekolah adalah perilaku menjahili temannya, berteriak-teriak hingga mengganggu orang lain, memukul, berkata kasar, dan ramai sendiri hingga membuat gaduh lingkungan.

Di Panti Asuhan, Bagus kerap mengeluhkan bahwa dirinya sakit kepala, dada sakit, dan beberapa keluhan sakit lainnya. Ketika ditanya lebih jauh dan diminta untuk diperiksakan ke dokter, ia menolaknya. Pernah pula Bagus naik ke atas genteng dan mengatakan bahwa dirinya ingin lompat. Ia kerap mengatakan "Tidak ada yang sayang dan perhatian denganku".

\section{Hasil Tes Psikologi}

Berdasarkan asesmen kecerdasan dengan menggunakan Standar Progressive Matrices (SPM), Bagus memiliki skor 43 sehingga dapat dikategorikan memiliki tingkat inteligensi rata-rata karena menghasilkan persentil 25 dan berada pada tingkat atau grade (III-). Asesmen kepribadian menggunakan Tes Proyektif (BAUM, DAP, HTP, dan Wartegg) menunjukkan bahwa Bagus memiliki kebutuhan yang besar akan rasa aman, serta membutuhkan banyak dorongan. Ada kecenderungan untuk mengharapkan perhatian dan kasih sayang dari orang lain. Jika dibandingkan dengan anak-anak seusianya, Bagus memiliki kontrol diri yang kurang baik. Kendali dirinya cenderung kaku didasari atas rasa tertekan dan tidak mampu. Sering kali ia membiarkan dorongan-dorongan dengan kontrol yang tidak cermat. Lebih jauh, titik berat klien lebih pada keinginan, ingin berkuasa, angkuh, dan sombong. Hal ini sering kali sebagai kompensasi dirinya untuk menutupi perasaan inferiornya. Bagus juga mengalami kesulitan di dalam mengekspresikan emosinya. Hal ini tidak terlepas dari kecenderungan Bagus yang impulsif dan sulit untuk tenang.

Asesmen kepribadian juga menunjukkan bahwa Bagus memiliki kebutuhan yang besar untuk bisa menjalin hubungan interpersonal dengan orang lain. Hal ini didasari oleh keinginannya untuk mendapatkan perhatian dan pengakuan dari orang lain. Hanya saja, Bagus kurang memiliki kemampuan manajemen konflik yang baik. Hal ini mengarahkannya kepada perilaku-perilaku yang kurang sesuai dengan norma ketika menghadapi konflik. Pola pemikiran Bagus juga tampak cenderung bersifat egosentris. Salah satunya disebabkan karena perasaan tidak aman yang besar pada dirinya. Bagus tampak memiliki kebutuhan untuk bisa lebih dekat dengan figur ibunya. Tampak adanya perasaan kurang berperan, kurang mampu dipercaya, kurang diperhatikan, dan kurang berharga pada Bagus di dalam lingkungan keluarganya.

\section{Riwayat Perkembangan}

Untuk mendapatkan gambaran yang lebih jelas, riwayat kehidupan Bagus sejak kecil telah dirangkum pada Tabel 1. 
Tabel 1. Rangkuman Riwayat Perkembangan Bagus

\begin{tabular}{|c|c|}
\hline Waktu & Peristiwa \\
\hline $\begin{array}{l}\text { Masa kecil } \\
\text { (0-5 tahun) }\end{array}$ & $\begin{array}{l}\text { - Kehamilan Bagus yang normal (9 bulan), tidak ada kelainan } \\
\text { - Lahir secara normal dan tidak ada keluhan yang ditemukan } \\
\text { - Pada usia } 4 \text { tahun, lahir adik Bagus sehingga perhatian Ibu Bagus cenderung menjadi } \\
\text { terpusat kepada sang adik } \\
\text { - Bagus tinggal bersama orangtuanya hingga masa kanak-kanak } \\
\text { - Kakak tiri Bagus sempat tidak mau menerima kehadiran Bagus dan adiknya (tidak } \\
\text { mengakui karena tidak menginginkan punya adik lagi); kakak kerap memarahi dan } \\
\text { menunjukkan perilaku kasar pada Bagus dan adiknya }\end{array}$ \\
\hline $\begin{array}{c}\text { Masa } \\
\text { kanak-kanak } \\
\text { (TK-SD) }\end{array}$ & $\begin{array}{l}\text { - Kedua orangtua Bagus sering bertengkar dan memilih untuk berpisah (pisah ranjang); } \\
\text { Bagus tidak memiliki sumber kasih sayang yang utuh } \\
\text { - Bagus sering menjahili adik, kakak, dan teman-temannya; Bagus tergolong anak yang } \\
\text { aktif, lincah, dan sulit untuk diam; pernah suatu hari Bagus merusakkan HP milik } \\
\text { kakaknya sehingga kakak sangat marah dan membencinya } \\
\text { - Bagus sering dimarahi oleh ibunya karena sulit untuk diatur; terkadang pula sering } \\
\text { dibanding-bandingkan dengan adiknya yang dipandang ibunya lebih menurut } \\
\text { - Usia } 9 \text { tahun Bagus dititipkan di Pondok Pesantren (sempat dua kali pindah Pondok } \\
\text { Pesantren); di Pondok Pesantren Bagus mendapatkan perlakuan kasar dan keras dari } \\
\text { guru dan kakak kelasnya sehingga tidak betah } \\
\text { - Di Pondok Pesantren sering kali mengusili adiknya, jika adik tidak mau mencucikan } \\
\text { bajunya maka akan dipukul } \\
\text { - Sering kali ngambeg di rumah (dengan ibu) dan kerap pergi tanpa ijin (minggat) ke } \\
\text { rumah ayahnya di Turi dengan berjalan kaki sendiri; jika marah senang memukul- } \\
\text { mukulkan kepalanya sendiri ke tembok } \\
\text { - Bagus dipindahkan ke Panti Asuhan }\end{array}$ \\
\hline $\begin{array}{c}\text { Masa } \\
\text { remaja awal } \\
\text { (SD akhir- } \\
\text { sekarang) }\end{array}$ & $\begin{array}{l}\text { - Kedua orangtua Bagus resmi bercerai } \\
\text { - Mulai menginjak masa remaja; Bagus mulai memiliki ketertarikan dengan lawan } \\
\text { jenisnya; mengaku senang dengan salah satu anak di Panti Asuhan } \\
\text { - Sering kali mengganggu teman-temannya di sekolah dan di Panti Asuhan } \\
\text { - Dipandang oleh pegawai panti sebagai anak yang kurang memiliki sopan santun, } \\
\text { agresif, bandel, sulit diatur, dan suka membuat ulah } \\
\text { - Dikeluhkan guru hampir setiap harinya karena senang membuat ulah di sekolah }\end{array}$ \\
\hline
\end{tabular}

\section{Diskusi}

Sejak kecil, Bagus sering diperlakukan keras dan kasar oleh ibunya. Kata-kata keras, kalimat-kalimat labeling, serta hukuman fisik membuatnya kurang mampu menghargai ibunya. Pengalaman tersebut juga berpengaruh terhadap bagaimana Bagus menilai dan menggambarkan dirinya sendiri. Santrock (2011) menjelaskan bahwa masa kanakkanak merupakan masa pertumbuhan dan pembelajaran yang pesat. Pengalaman yang diperoleh anak pada masa ini memiliki dampak yang besar terhadap perkembangannya di masa depan. Albert Bandura mengungkapkan bahwa anak adalah seorang pembelajar yang paling cepat. Anak-anak akan melakukan proses belajar melalui pengamatan terhadap apa yang dilakukan orang lain (Santrock, 2011). Pada masa ini, anak juga mengembangkan kemampuan untuk membedakan antara apa yang menjadi milik atau bagian dari dirinya dan hal-hal lain yang dilihat, didengar, diraba, atau diciumnya ketika dia mulai membentuk suatu lukisan dan 
gambaran tentang siapa dirinya (perkembangan konsep diri) (Schultz, 1991).

Bagus berasal dari keluarga yang bercerai. Kedua orangtuanya telah lama berpisah dan tidak tinggal satu rumah lagi. Sumber kasih sayang dan perhatian yang dimiliki Bagus sudah tidak lengkap lagi. Figur ibu yang seharusnya dapat memenuhi kebutuhan afeksinya, namun dipandang Bagus kurang mampu memenuhi kebutuhan afeksinya karena ibunya dipandang sebagai sosok yang keras dan emosional serta memiliki keterbatasan ekonomi. Akibatnya, Bagus pun berusaha mencari figur lain yang dapat menggantikannya, salah satunya adalah ayah kandungnya yang tinggal terpisah dengannya. Hal inilah yang menjadi alasan Bagus kerap pergi tanpa izin dari rumah ibunya ke rumah ayahnya, terutama ketika ia sedang merasa kecewa dan marah dengan ibunya. Bagus benar-benar mendambakan sosok yang mampu memuaskan kebutuhan afeksinya. Namun ternyata pada kenyataannya ayah Bagus pun juga dipandang kurang mampu memenuhi kebutuhan afeksinya, bahkan untuk memenuhi kebutuhan ekonomi sehari-harinya saja dirasa kesulitan. Sebagai kompensasinya, Bagus selalu berusaha untuk mendapatkan perhatian dan kasih sayang di luar dari kedua orangtuanya dengan cara dan pemikirannya sendiri.

Bagus tidak mengembangkan kelekatan (attachment) yang baik dengan orangtuanya. Santrock (2011) menjelaskan kelekatan sebagai ikatan emosional yang erat antara dua orang. Pada masa bayi, kontak yang menimbulkan rasa nyaman dan kepercayaan menjadi faktor penting dalam perkembangan kelekatan. Kelekatan yang aman (secure attachment) diharapkan dapat mampu mengurangi risiko munculnya perilaku maladaptif. Sebaliknya, anak dengan kelekatan yang penuh dengan rasa kecemasan dapat berisiko untuk mengalami depresi, kemandirian yang kompulsif, agoraphobia, rasa berkabung yang kronis dalam peristiwa-peristiwa, kenakalan yang persisten, serta masalah yang berkaitan dengan kecemasan, kemarahan, dan keintiman (Colin, 1996). Secure attachment juga berkaitan dengan perkembangan yang lebih positif pada masa kanak-kanak, seperti harga diri yang lebih tinggi dan hubungan dengan teman sebaya yang lebih baik, daripada insecure attachment (dalam Leon, 2003). Pada kasus Bagus, terjadinya perceraian orangtua mengganggu kelekatan yang aman pada anak. Ditambah lagi adanya pertengkaran orangtua yang menghambat tercapainya secure attachment pada anak (dalam Leon, 2003). Sikap ibu yang kerap menjelek-jelekkan sang ayah di depan Bagus juga menjadi pengaruh yang negatif bagi Bagus.

Kedua orangtua Bagus kerap bertengkar sejak Bagus kecil. Perceraian yang terjadi membuat Bagus semakin tertekan. Banyak studi menunjukkan bahwa perceraian memiliki efek yang negatif pada perkembangan anak. Anakanak yang orangtuanya bercerai akan menanggung beban besar yang mereka tidak dapat pahami sendiri. Mereka juga cenderung akan menyalahkan diri mereka sendiri, memiliki kekhawatiran tentang siapa yang akan merawat mereka, dengan siapa mereka akan tinggal, dan bagaimana 
mereka harus memilih antara dua orang tua (dalam Mahmud, Yunn, Aziz, Salleh, \& Amat, 2011). Wyman, Cowen, Hightower, dan Pedro-Caroll (1985) dalam studinya menemukan bahwa anak-anak dengan orangtua bercerai memiliki tingkat kecemasan yang tinggi serta memandang kompetensi kognitif diri mereka jauh lebih rendah dibandingkan mereka yang tinggal dalam keluarga utuh. Studi metanalisis Amato (dalam Wenar \& Kerig, 2006) juga menunjukkan bahwa anak-anak dengan orangtua yang bercerai memiliki tingkat penyesuaian psikologis, harga diri, serta pencapaian akademik yang lebih rendah dibandingkan anak-anak dengan keluarga utuh. Banyak dari mereka mengalami masalah perilaku dan kesulitan menjalin hubungan interpersonal.

Sama halnya dengan yang terjadi pada Bagus dimana ia menyimpan rasa kecemasannya sejak kecil. Tahun-tahun awal kehidupan yang merupakan perkembangan konsep diri anak (Schultz, 1991) menjadi kabur dan mengarahkannya kepada tingkat keberhargaan diri yang rendah, terlebih karena perceraian dan konflik orangtua (Leon, 2003). Hilangnya figur yang seharusnya dapat memenuhi kebutuhan afeksi membuat anak merasa semakin tidak berharga dalam keluarga (hal ini terlihat dalam hasil tes grafis). Bagi Bagus, keluarganya tidak dapat memberikan perhatian yang diharapkan sehingga ia berusaha untuk melakukan halhal yang dapat mendatangkan perhatian dari orang-orang di sekitarnya, seperti mengganggu teman, memukul, berteriakteriak, berkata-kata kotor, ramai di kelas, dan lain sebagainya. Dengan berperilaku demikian, dirinya menjadi merasa diperhatikan oleh orang-orang di sekitarnya.

$$
\text { Maccoby (dalam Leon, 2003) }
$$
mengatakan bahwa pada masa prasekolah, anak-anak belajar untuk mengembangkan kontrol diri dan kemampuan untuk mengatur perilaku mereka. Pada beberapa kasus, anak-anak mungkin masih mengalami kesulitan di dalam mengatur perilaku mereka terutama yang berhubungan dengan perasaan yang kuat seperti rasa takut, marah, atau sedih. Perceraian orangtua dapat membangkitkan emosi yang kuat tersebut sehingga akan mempengaruhi regulasi perilaku mereka. Perasaan tertekan anak-anak kerap diekspresikan dalam bentuk perilaku karena kemampuan verbal yang masih terbatas. Hal inilah yang terjadi pada Bagus sejak kecil dimana kekecewaannya selalu diekspresikan dengan perilaku-perilaku yang kurang tepat hingga sampai saat ini.

Berdasarkan pendekatan kognitif keperilakuan, kasus Bagus dapat dijelaskan bahwa kondisi yang dialami merupakan akibat adanya pemikiran dan pemahaman yang salah. Dengan mengidentifikasi pengalaman awal (early experience) seseorang, maka akan mampu membantu menemukan bagaimana ia mengembangkan core belief atau kepercayaan tertentu yang mempengaruhi perilaku mereka dalam waktu sekarang ini. Hal ini karena core belief terkadang muncul tidak disadari karena sudah terbentuk sejak kecil. Core belief sendiri merupakan kepercayaan paling mendasar yang terkadang salah diinterpretasi oleh seseorang sebagai kebenaran dan fakta. 


\section{PRAPTOMOJATI}

Secondary belief atau conditional belief merupakan asumsi negatif yang menghubungkan belief dengan cara berpikir sehari-hari. Conditional belief ini juga membuat peraturan untuk hidup. Beliefs ini kemudian dihubungkan oleh assumption ke pemikiran sehari-hari (automatic thoughts). Assumptions adalah ide yang didapatkan oleh seseorang mengenai dirinya sendiri, orang lain, dan kehidupan pada umumnya yang menyebabkan individu mengembangkan aturan dalam hidup tertentu. Assumptions ini juga menimbulkan aturan dalam hidup untuk melindungi diri (Wilding \& Milne, 2008).

Dalam kasus, Bagus memiliki keyakinan bahwa dirinya tidak disayang dan diperhatikan oleh siapapun. Kemudian hal ini memunculkan asumsi bahwa ia akan mendapatkan perhatian jika mengganggu orang lain. Dengan begitu, ketika subjek berhadapan pada situasi tertentu atau berinteraksi dengan orang lain, negative automatic thought yang muncul pertama kali adalah "Aku harus bandel dan mengganggu orang lain agar diperhatikan". Berdasarkan pola pemikiran yang salah tersebut maka memunculkan pola perilaku yang tidak tepat seperti menjahili teman-teman, memukul, berkata-kata kotor, berteriakteriak hingga mengganggu, atau membuat gaduh lingkungan. Secara ringkas, dinamika psikologis Bagus berdasarkan pendekatan kognitif keperilakuan dapat dilihat pada Gambar 1.

\section{Early Experience}

- Sejak kecil selalu dititipkan di institusi yang mau menampungnya (Pondok Pesantren, Panti Asuhan)

- Kedua orangtua yang tidak akur dan sering bertengkar sehingga sangat sedikit sumber perhatian dan kasih sayang yang didapatkan

- Seringnya dibanding-bandingkan dengan adiknya; kakak tiri sangat membencinya

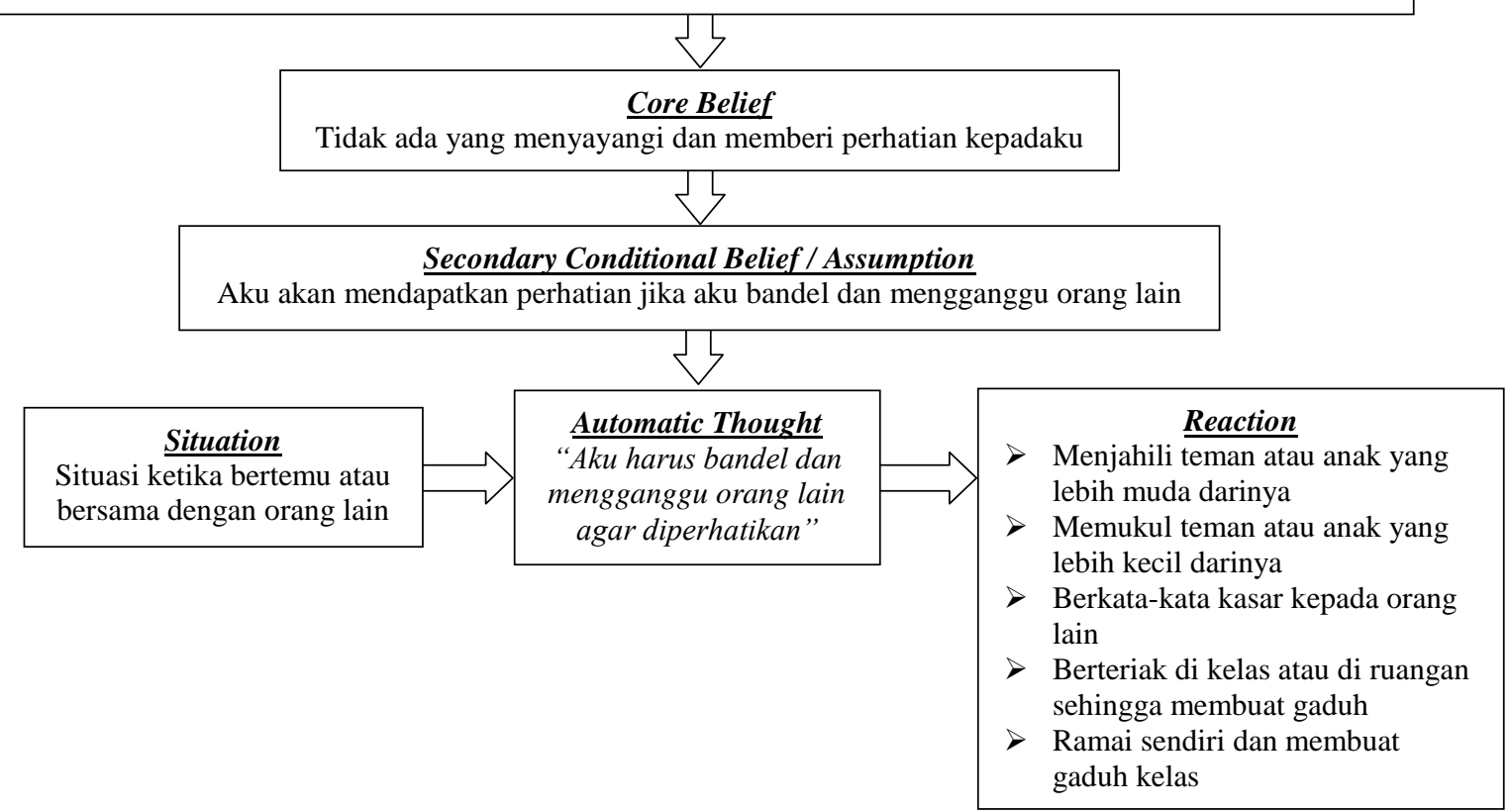

Gambar 1. Dinamika Psikologis Bagus berdasar Teori Kognitif Keperilakuan 
Untuk memahami permasalahan subjek lebih jauh, sangat penting pula untuk mengidentifikasi faktor risiko dan faktor protektif pada subjek. Faktor risiko adalah segala kondisi yang dapat mendorong muncul dan berkembangannya psikopatologi, sedangkan faktor protektif adalah segala hal yang mampu mendukung dan menjaga perkembangan yang positif dari anak (Wenar \& Kerig, 2006). Analisis faktor risiko dan faktor protektif menjadi sangat penting untuk menjadi dasar pengambilan langkah yang tepat dalam usaha pengatasan permasalahan anak. Hal ini sebagai cara untuk mempertahankan anak agar mampu berkembang tetap berada pada garis perkembangan yang normal. Analisis faktor risiko dan faktor protektif Bagus berdasarkan konsep Wenar dan Kerig (2006) dapat dilihat pada Tabel 2.

Tabel 2. Analisis Faktor Risiko dan Faktor Protektif Bagus

\begin{tabular}{|c|c|c|}
\hline Konteks & Faktor Risiko & Faktor Protektif \\
\hline $\begin{array}{l}\text { Organis } \\
\text { (Biologis) }\end{array}$ & - Tidak ditemukan & $\begin{array}{l}\text { - Berdasarkan hasil asesmen, Bagus tidak } \\
\text { memiliki hambatan fisik dan organik }\end{array}$ \\
\hline $\begin{array}{l}\text { Intrapersonal } \\
\text { (Individual) }\end{array}$ & $\begin{array}{l}\text { - Bagus memiliki perasaan inferior dan } \\
\text { keberhargaan diri yang rendah } \\
\text { - Bagus memiliki kontrol diri yang masih } \\
\text { kurang berkembang dengan baik } \\
\text { - Bagus sulit fokus dan perhatiannya } \\
\text { mudah teralihkan; motivasi untuk } \\
\text { belajar rendah }\end{array}$ & $\begin{array}{l}\text { - Bagus memiliki potensi kecerdasan } \\
\text { yang cukup baik: Skala SPM masuk } \\
\text { dalam grade III- (Intelectually Average); } \\
\text { masih masuk dalam kategori rerata } \\
\text { yang berarti memiliki tingkat } \\
\text { kecerdasan normal ketika dibandingkan } \\
\text { dengan anak-anak seusianya. }\end{array}$ \\
\hline $\begin{array}{l}\text { Interpersonal } \\
\text { Family }\end{array}$ & $\begin{array}{l}\text { - Hubungan ayah dan ibu tidak } \\
\text { harmonis, sering bertengkar di } \\
\text { depannya. } \\
\text { - Sumber kasih sayang yang terbatas, } \\
\text { mengingat kedua orangtua telah } \\
\text { bercerai dan tinggal terpisah } \\
\text { - Ibu emosional dan kerap memarahi dan } \\
\text { menghukum (secara fisik dan nonfisik) } \\
\text { - Ayah cenderung mengabaikan Bagus } \\
\text { - Kelekatan yang kurang berkembang } \\
\text { dengan sehat (insecure attachment) sejak } \\
\text { Bagus kecil }\end{array}$ & $\begin{array}{l}\text { - Adanya figur kakak tiri yang perhatian, } \\
\text { peduli, dan sayang kepadanya } \\
\text { - Bagus memiliki seorang adik laki-laki } \\
\text { yang pada dasarnya ia sayangi dan } \\
\text { biasanya menjadi teman bermain dan } \\
\text { bercanda }\end{array}$ \\
\hline $\begin{array}{l}\text { Interpersonal } \\
\text { Peer (Sosial) }\end{array}$ & $\begin{array}{l}\text { - Bagus kerap dibenci oleh teman- } \\
\text { temannya karena dipandang bandel, } \\
\text { suka berkelahi, suka mengganggu, dan } \\
\text { kasar }\end{array}$ & $\begin{array}{l}\text { - Bagus memiliki banyak teman } \\
\text { bersosialisasi di Panti Asuhan } \\
\text { - Bagus memiliki figur orang dewasa } \\
\text { yang mengawasi dan memberikan } \\
\text { perhatian selama di Panti Asuhan, yaitu } \\
\text { pramusosial dan pekerja sosial }\end{array}$ \\
\hline $\begin{array}{l}\text { Superordinate } \\
\text { (Cultural) }\end{array}$ & $\begin{array}{l}\text { - Kondisi ekonomi keluarga yang serba } \\
\text { terbatas (termasuk menengah ke } \\
\text { bawah) }\end{array}$ & $\begin{array}{l}\text { - Bagus tinggal di Panti Asuhan dimana } \\
\text { semua kebutuhan sehari-harinya dapat } \\
\text { terpenuhi; adanya teman-teman yang } \\
\text { banyak; adanya kesempatan untuk } \\
\text { bersekolah }\end{array}$ \\
\hline
\end{tabular}




\section{Penutup}

Hasil penelitian ini menunjukkan bahwa perhatian dan kasih sayang dari orangtua dan orang-orang di sekitarnya menjadi suatu hal yang didambakan oleh anak dan remaja, tidak terkecuali subjek. Keluarga subjek telah bercerai sehingga orangtua subjek kurang mampu memberikan kebutuhan afeksi pada subjek secara penuh. Hal ini kemudian mengarahkan subjek untuk melakukan perilaku-perilaku maladaptif dengan tujuan untuk mendapatkan perhatian dari orangorang di sekitarnya. Adanya labelling dan hukuman yang keras baik secara verbal maupun nonverbal dari ibu membentuk subjek menjadi remaja yang inferior dan memiliki pola pikir yang maladaptif. Untuk mengkompensasi perasaan inferiornya tersebut, ia melakukan tindakan-tindakan yang kurang tepat karena dipandangnya mampu mendatangkan perhatian dari orang lain. Hal ini didapatkannya dari proses belajarnya yang salah selama ini. Adanya pola berpikir yang salah yakni "Aku akan mendapatkan perhatian jika aku bandel dan mengganggu orang lain" menjadi dasar munculnya perilaku maladaptif tersebut. Berdasarkan temuan penelitian, menjadi sangat penting bagi orangtua untuk dapat menanamkan nilai-nilai dan pemikiran positif kepada anak sejak dini. Dalam hal ini bukan berarti anak korban perceraian pasti akan mengalami kenakalan remaja. Hal ini kembali lagi kepada peran dan pola asuh orangtua dalam mendidik dan mengasuh anak, salah satunya dalam pemenuhan kebutuhan afeksi, kasih sayang, dan pemahaman diri pada anak.

\section{Daftar Pustaka}

Adofo, P. Y. \& Etsey, Y. K. A. (2016). Family processes in one-parent, step parent, and intact families: The child's point of view. Pyrex Journal of Psychology and Counseling, 2(4), 21-27.

American Psychiatric Association. (2000). Diagnostic and statistical manual of mental disorders fourth edition text revision. Washington, DC: Author.

Aseltine, R. H. (1992). The impact of parental divorce on adolescents (Disertasi tidak dipublikasikan). University of Michigan, Michigan.

Babalis, T., Tsoli, K., Nikolopoulos, V., \& Maniatis, P. (2014). The effect of divorce on school performance and behavior in preschool children in Greece: An Empirical Study of Teachers' Views. Scientific Research, Psychology, 5(1), 20-26.

Badan Pusat Statistik. (2017). Nikah, Talak dan Cerai, serta Rujuk, 2012-2015. Diunduh dari https://www.bps.go.id/linkTableDinam is/view/id/893

Beck, J. S. (2011). Cognitive behavior therapy: Basics and beyond (2nd ed.). New York: The Guilford Press.

Blattner, M. C. C., Liang, B., Lund, T., \& Spencer, R. (2013). Searching for a sense of purpose: The role of parents and effects on self-esteem among female adolescents. Journal of Adolescence, 36, 839-848.

Colin, V. L. (1996). Human attachment. New York: McGraww-Hill Companies, Inc.

Çivitci, N., Çivitci, A., \& Fiyakali, N. C. (2009). Loneliness and life satisfaction in adolescents with divorced and nondivorced parents. Educational Sciences: Theory \& Practice 9(2), 513-525 
Dewi, P. S. \& Utami, M. S. (2008). Subjective well-being anak dari orang tua yang bercerai. Jurnal Psikologi, 35(2), 194 212.

Emam, M. M. \& Abu-Serei, U. S. (2014). Family functioning predictors of selfconcept and self-esteem in children at risk for learning disabilities in Oman: Exclusion of parent and gender contribution. International Education Studies, 7(10), 89-99.

Esmaeili, N. S. \& Yaacob, S. N. (2012). Correlates of self-esteem among adolescents of divorced families. Archives Des Sciences, 65(8), 52-59.

Eymann, A., Busaniche, J., Llera, J., Cunto, C. D., \& Wahren, C. (2009). Impact of divorce on the quality of life in schoolage children. Jornal de Pediatria, 85(6), 547-552.

Fagan, P. F. \& Churchill, A. (2012). The Effects of Divorce on Children. Marri Research. Diunduh dari http://marri.us/wpcontent/uploads/publications/research_ papers/EF12A22. pdf

Fry, J. A. (2010). Change in family structure and rates of violent juvenile delinquency (Tesis tidak dipublikasikan). Virginia Polytechnic Institute and State University, Virginia.

Hurlock, E. B. (2002). Development psychology: A life-span aprroach (Psikologi Perkembangan, Suatu pendekatan sepanjang rentang kehidupan). Diterjemahkan oleh Istiwidayanti dan Soedjarwo. Jakarta: Erlangga.

Kagan, J. (1999). The role of parents in children's psychological development. Pediatrics, 104(1). 164-167.
Lansford, J. E. (2009). Parental divorce and children's adjustment. Perspectives on Psychological Science, 4(2), 140-152

Leon, K. (2003). Risk and protective factors in young children's adjustment to parental divorce: a review of the research. Family Relations, 52, 258-270.

Mackay, R. (2005). The impact of family structure and family change on child outcomes: a personal reading of the research literature. Social Policy Journal of New Zealand, 4, 111-133.

Mahmud, Z., Yunn, Y. P., Aziz, R., Salleh, A., \& Amat S. (2011). Counseling children of divorce. World Applied Sciences Journal 14 (Learning Innovation and Intervention for Diverse Learners), 2127.

Mishra, S. \& Shanwal, V. K. (2014). Children's self-concept and perception of parents' behavior. Children's SelfConcept and Perception of Parents' Behavior, 1(1), 28-30.

Morrison, D. R. \& Coiro, M. J. (1999). Parental conflict and marital disruption: Do children benefit when high-conflict marriages are dissolved? Journal of Marriage and Family, 61(3), 626-637.

Needle, R. H., Su, S. S., \& Doherty, W. J. (1990). Divorce, remarriage, and adolescent substance use: A prospective longitudinal study. Journal of Marriage and Family, 52(1), 157-169

Poerwandari, K. (2001). Pendekatan kualitatif untuk penelitian perilaku manusia. Jakarta: LPSP3 Fakultas Psikologi Universitas Indonesia.

Pálmarsdóttir, H. M. L. (2015). Parental divorce, family conflict and adolescent depression and anxiety (Tesis tidak 
dipublikasikan). Reykjavik University, Reykjavik.

Santrock, J. W. (2011). Life-Span Development (13 ${ }^{\text {th }}$ Ed.). New York: McGraw-Hill.

Singh, H. \& Kiran, U. V. (2012). Effect of single parent family on child delinquency. International Journal of Science and Research (IJSR), 3(9), 866868.

Schultz, D. (1991). Psikologi pertumbuhan, model-model kepribadian sehat. Yogyakarta: Kanisius.

Thompson Jr, R. G., Lizardi, D., Keyes, K. M., \& Hasin, D. S. (2008). Childhood or adolescent parental divorce/separation, parental history of alcohol problems, and offspring lifetime alcohol dependence. Drug and Alcohol Dependence, 98, 264-269.

Thornberry, T. P., Smith, C. A., Rivera, C., Huizinga, D., \& Stouthamer-Loeber, M. September (1999). Family disruption and delinquency. Juvenile Justice Bulletin. 1-7.

Uphold-Carrier, H. \& Utz, R. (2012). Parental divorce among young and adult children: A long-term quantitative analysis of mental health and family solidarity. Journal of Divorce $\mathcal{E}$ Remarriage, 53(4), 247-266.

Yabiku, S. T., Axinn, W. G., \& Thornton, A. (1999). Family integration and children's self-esteem. American Journal of Sociology, 104(5), 1494-1524.

Weber, A. D. (2001). Influence of family environment on self-esteem and hostility (Disertasi tidak dipublikasikan). Southern Illinois University, Carbondale.
Wells, L. E. \& Rankin, J. H. (1991). Families and delinquency: A meta-analysis of the impact of broken homes. Social Problems, 38(1), 71-93.

Wenar, C. \& Kerig, P. (2006). Developmental psychopathology: From infancy through adolescence (5 th $^{\text {Ed. }}$.). London: McGrawHill.

Wilding, C., Milne, A. (2008). Cognitive behavioural therapy. London: Hodder Headline.

Wyman, P. A., Cowen, E. L., Hightower, A. D., Pedro-Carroll, J. L. (1985). Perceived competence, self-esteem and anxiety in latency-aged children of divorce. Journal of Clinical Child Psychology, 14(1), 20-26. 